\title{
STRATEGI PEMERINTAH DAERAH DALAM PEMBERDAYAAN KELOMPOK TANI DI DESA LASIAI KECAMATAN SINJAI TIMUR KABUPATEN SINJAI
}

\author{
Jusrang ${ }^{1}$, Andi Luhur Prianto ${ }^{1}$ \\ 1Program Studi Ilmu Pemerintahan Fakultas Ilmu Sosial dan Ilmu Politik \\ Universitas Muhammadiyah Makassar \\ Jl. Sultan Alauddin No. 259 Makassar 90221 \\ Telp. 0411-866972 ext.107.Fax.0411-8655888 \\ jusrang92@yahoo.com luhur@unismuh.ac.id
} ABSTRACT

The purpose of research is to find out how the local governments in the strategy to empower the farmer in the village of Lasiai, District East Sinjai, Regency of Sinjai. This type of research is qualitative and descriptive type of research is phenomenological, with 15 informant people. Sources of data in this research is data of primary and secondary data, data collection techniques in this study is observation, interviews, documentation and FGD conducted directly by researchers. Technical analysis the data in this study is the reduction of data, serving data and verification and validation method the data in this study is a triangulation of sources, methods and triangulation time. The results showed that the local government strategy empowerment of farmers group with indicators such as using SWOT analysis is Strength, Weakness, Opportunity and Threat indicators using SWOT analysis to determine the internal and external factors in the local government to empower farmer groups so that the self-reliance of farmer groups in the village Lasiai.

Keywords: strategy, government, empowerment, farmers' groups

\begin{abstract}
ABSTRAK
Tujuan penelitian adalah untuk mengetahui bagaimana strategi pemerintah daerah dalam pemberdayaan kelompok tani di Desa Lasiai, Kecamatan Sinjai Timur, Kabupaten Sinjai. Jenis penelitian adalah deskriptif kualitatif dan tipe penelitian ini adalah fenomenologis dengan informan 15 orang. sumber data dalam penelitian ini adalah data primer dan data sekunder, teknik pengumpulan data dalam penelitian ini adalah observasi, wawancara, dokumentasi dan FGD yang dilakukan secara langsung oleh peneliti teknik analisi data dalam penelitian ini adalah reduksi data, sajian data dan verifikasi dan teknik pengabsahan data dalam penelitian ini adalah triangulasi sumber, triangulasi metode dan triangulasi waktu. Hasil penelitian menunjukkan bahwa strategi pemerintah daerah dalam pemberdayaan kelompok tani dengan indikator yaitu menggunakan analisis SWOT yaitu Strenght, Weakness, Opportunity Dan Threat dengan indikator menggunakan analisis SWOT untuk mengetahui faktor internal maupun faktor eksternal pemerintah daerah dalam melakukan pemberdayaan kelompok tani sehingga terwujudnya kemandirian kelompok tani di Desa Lasiai.
\end{abstract}

Kata Kunci : strategi, pemerintah, pemberdayaan, kelompok tani 


\section{A. PENDAHULUAN}

Kebijakan pertanian mempengaruhi kehidupan semua orang, termasuk kesejahteraannya. Reaksi setiap orang terhadap suatu kebijakan akan berbeda-beda tergantung pada keadaan masing-masing dan dampak kebijakan tersebut pada pendapatan, kekayaan, dan kepentingan lainnya. Kebijakan pertanian merupakan public policy di bidang pertanian, salah satu bentuk social control untuk mencapai tujuan tertentu, misalnya tujuan pembangunan pertanian dan isi pokok tujuan pembangunan pertanian tersebut ada kesamaannya walaupun dengan rumusan dan tekanan yang berbeda-beda yaitu untuk meningkatkan produksi, memperluas kesempatan kerja, dan meningkatkan pemerataan kegiatan pembangunan pertanian, dengan meningkatkan pendapatan dan taraf hidup, pelestarian sumberdaya, dan sebagainya.

Dalam mencapai peningkatan pembangunan pertanian, peranan kelembagaan kelompok tani di pedesaan sangat besar dalam mendukung dan melaksanakan berbagai program yang sedang dan akan dilaksanakan karena kelompok tani inilah pada dasarnya pelaku utama pembangunan pertanian. Dengan demikian perlunya pembangunan pertanian yang betul-betul mampu meningkatkan produktivitas, sehingga ketahanan pangan mandiri dapat tercapai. Membangun pertanian kunci keberhasilan terletak pada SDM, artinya bagaimana meningkatkan kemampuan sumber daya manusianya yang ada, baik dari segi ketrampilan, pengetahuan dan sikap mental para petani, dengan demikian pembangunan pertanian yang tangguh harus dilandasi dengan membangun dan memberdayakan kelompok tani, sehingga kelompok tani mampu menganalisa dan menyelesaikan masalah yang dihadapi secara mandiri.

Dalam upaya pengembangan kelompok tani, yang ingin dicapai adalah terwujudnya kelompok tani yang dinamis, dimana para petani mempunyai disiplin, tanggung jawab dan terampil dalam kerjasama mengelola kegiatan usaha taninya serta dalam upaya meningkatkan skala usaha dan peningkatan usaha kearah yang lebih besar dan bersifat komersil. Berdasarkan data dari Kantor Penyuluhan Pertanian di Kabupaten Sinjai, pada tahun 2014 jumlah kelompok tani di Kabupaten sinjai adalah sebanyak 1.124 Kelompok tani khususnya di Desa Lasiai jumlah kelompok tani adalah 12 kelompok tani.

Salah satu masalah yang dihadapi oleh 12 kelompok tani yang ada Di Desa Lasiai yaitu masalah pemberdayaan karena Kelompok tani masih tergantung kepada pemerintah dan masih ada intervensi dari pemerintah daerah terhadap kelompok tani dalam artian kelompok tani masih belum bisa berdiri sendiri atau belum mampu mandiri, ketergantungan ini membuktikan bahwa kelompok tani yang ada Di Desa Lasiai masih jauh dari kata mandiri. Ketidakberdayaan kelompok tani itu dapat dilihat ketidakmampuan mereka menghadapi masalah-masalah yang menimpa mereka terutama misalnya adanya gagal panen sehingga membuat kelompok tani menjadi terpuruk sehingga tidak mampu memenuhi kebutuhan sehari-harinya.

Melihat permasalahan yang ada di Desa Lasiai, Kecamatan Sinjai Timur, Kabupaten Sinjai, maka penulis tertarik melakukan penelitian mengenai strategi pemerintah daerah dalam pemberdayaan kelompok tani untuk meningkatkan kesejahteraan dan kemandirian kelompok tani di Desa Lasiai, Kecamatan Sinjai Timur, Kabupaten Sinjai. Adapun tujuan penelitian ini adalah untuk mengetahui strategi pemerintah daerah dalam pemberdayaan kelompok tani di Desa Lasiai, Kecamatan Sinjai Timur, Kabupaten Sinjai.

\section{B. KONSEP STRATEGI}

Strategi menurut Kamus Besar Bahasa Indonesia memiliki beberapa arti yaitu siasat perang, ilmu siasat perang, tempat yang baik menurut siasat perang, atau dapat pula diartikan sebagai rencana yang cermat mengenai kegiatan untuk mencapai sasaran khusus.

Marrus (2002) mendefinisikan strategi merupakan sutau proses penentuan rencana para pemimipin puncak yang berfokus pada tujuan jangka panjang 
organisasi, disertai penyusunan suatu cara atau upaya bagaimana agar tujuan tersebut tercapai.

\section{KONSEP PEMERINTAH DAERAH}

Menurut UU No 23 Tahun 2014 dalam Pasal 1, yang dimaksud Pemerintahan Daerah adalah penyelenggaraan urusan pemerintahan oleh pemerintah daerah dan dewan perwakilan rakyat daerah menurut asas otonomi dan tugas pembantuan dengan prinsip otonomi seluasluanya dalam sistem dan prinsip Negara Kesatuan Republik Indonesia sebagaimana dimaksud dalam Undang-Undang Dasar Negara Republik Indonesia Tahun 1945. Sedangkan yang dimaksud Pemerintah Daerah adalah kepala daerah sebagai unsur penyelenggara Pemerintahan Daerah yang memimpin pelaksanaan urusan pemerintahan yang menjadi kewenangan daerah otonom.

\section{KONSEP PEMBERDAYAAN}

Pemberdayaan (empowerment) merupakan konsep yang berkaitan dengan kekuasaan (power). Istilah kekuasaan seringkali identik dengan kemampuan individu untuk membuat dirinya atau pihak lain melakukan apa yang di inginkannya. Kemampuan tersebut baik untuk mengatur dirinya, mengatur orang lain sebagai individu atau kelompok/organisasi, terlepas dari kebutuhan, potensi, atau keinginan orang lain.

\section{E. KONSEP STRATEGI PEMBERDAYAAN}

Dalam melaksanakan pemberdayaan perlu di lakukan melalui berbagai pendekatan. Menurut Suharto (2005:87) penerapan pendekatan pemberdayaan dapat di lakukan 5P yaitu: pemungkinan, penguatan, perlindungan, penyokongan, dan pemeliharaan, dengan penjelasan sebagai berikut: Pemungkinan adalah menciptakan suasana atau iklim yang memungkinkan potensi masyarakat berkembang secara optimal.. Pemberdayaan harus mampu membebaskan masyarakat dari sekarat-sekarat kultural dan struktur yang menghambat.

Memperkuat pengetahuan dan kemampuan yang dimiliki masyarakat dalam memecahkan masalah dan memenuhi kebutuhankebutuhannya. Pemberdayaan harus mampu menumbuh kembangkan segenap kemampuan dan kepercayaan diri masyarakat yang menunjang kemandirian mereka. Perlindungan adalah melindungi masyarakat terutama kelompok-kelompok lemah agar tidak tertindas oleh kelompok kuat, menghindari terjadinya persaingan yang tidak sehat antara yang kuat dan lemah, dan mencegah terjadinya eksploitasi kelompok kuat terhadap kelompok lemah.

Pemberdayaan harus diarahkan kepada penghapusan segala jenis diskriminasi dan dominasi yang tidak menguntungkan rakyat kecil. (1) Penyokongan adalah memberikan bimbingan dan dukungan agar masyarakat mampu menjalankan perannya dan tugastugas kehidupannya. Pemberdayaan harus mampu menyokong masyarakat agar tidak terjatuh ke dalam keadaan dan posisi yang semakin lemah dan terpinggirkan. (2) Pemeliharaan adalah memelihara kondisi yang kondusif agar tetap terjadi keseimbangan distribusi kekuasaan antara berbagai kelompok dalam masyarakat. pemberdayaan harus mampu menjamin keselarasan dan keseimbangan yang memungkinkan setiap orang memperoleh kesempatan berusaha.

\section{F. PENGERTIAN KELOMPOK TANI}

Pengertian Kelompok Tani Berdasarkan Peraturan Menteri Pertanian No.273/Kpts/OT.160/4/2007, kelompok tani adalah kumpulan petani/peternak/ pekebun yang dibentuk atas dasar kesamaan kepentingan, kesamaan kondisi, lingkungan (sosial, ekonomi, sumber daya) dan keakraban untuk meningkatkan dan mengembangkan usaha anggota.

\section{G. METODE PENELITIAN}

Pelaksanaan penelitian dilakukan selama 2 bulan. Penelitian ini berlokasi Di Kantor Dinas Pertanian Tanaman Pangan dan Holtikultura Kabupaten Sinjai. Dengan 
alasan peneliti memilih lokasi ini karena peniliti ingin mengetahui bagaimana strategi pemerintah daerah dalam melakukan pemberdayaan kepada kelompok tani sehingga meningkatkan kemampuan dan keterampilan kelompok tani untuk mampu mandiri dan bisa meningkatkan kesejahteraanya. Jenis penelitian yang digunakan dalam penelitian ini adalah deksriptif kualitatif. Tipe penelitian ini adalah fenomenologis dimaksudkan untuk memberi gambaran secara jelas mengenai fenomenafenomena yang terjadi dimasyarakat. Sumber data dalam penelitian ini yaitu Data primer adalah data yang diperoleh langsung melalui observasi dan wawancara yang berhubungan dalam penelitian.

Data sekunder adalah data-data yang diperoleh dari buku-buku dan dokumen yang mendukung dan berhubungan dengan pokokpokok pembahasan penelitian ini. Peneliti menggunakan teknik purposive sampling dalam menentukan informannya. Purposive sampling merupakan penentuan informan tidak berdasarkan atas strata, kedudukan, pedoman, atau wilayah tetapi didasarkan pada adanya tujuan dan pertimbangan tertentu yang tetap berhubungan dengan permasalahan peneliti. Untuk memperoleh data yang relevan sebagaimana yang diharapkan dalam tujuan penelitian, maka digunakan teknik pengumpulan data. Adapaun teknik pengumpulan data yang dilakukan dalam penelitian ini adalah: Wawancara, Observasi, Dokumentasi dan FGD.

Teknik Analisis Data Peneliti menggunakan deskripsi kualitatif sebagai metode analisis data. Adapun yang dimaksud dengan metode diskripsi adalah suatu cara mengembangkan data tersebut dalam bentuk kata-kata atau kalimat. Sedangkan pola pikir secara kaulitatif artinya hanya mengecek dan melaporkan apa yang ada ditempat diselenggarakannya penelitian. Teknik pengumpulan data, triangulasi diartikan sebagai teknik pengumpulan data yang bersifat menggabungkan dari berbagai teknik pengumpulan data dan sumber data yang telah ada.

\section{E. PENELITIAN DAN PEMBAHASAN}

Kondisi kelembagaan adalah situasi atau keadaan lembaga sekarang ini dalam artian bagaimana kondisi atau keadaan kelompok tani yang ada di Desa Lasiai atau bagaimana tingkat keterberdayaan kelompok tani yang ada di Desa Lasiai. Apakah kelompok tani yang ada di desa lasiai sudah ada yang layak dikatakan kategori kelompok tani mandiri atau belum ada.

Berikut hasil wawancara dengan beberapa informan terkait dengan kondisi kelembagaan atau tingkat keterberdayaan kelompok tani yang ada di Desa Lasiai.

"Menurut saya indikator kelompok tani layak dikatakan mandiri antara lain: (1). Kelengkapan buku administrasi (2). Mereka wajib melakukan pertemuan kelompok minimal satu kali sebulan (3). Kelompok tani harus mampu mengakomodir semua anjuran teknis penyuluh artinya dia mampu melaksanakan anjuran teknis yang diberikan penyuluh (4). Dia mampu mengakses modal usaha taninya apakah lewat BRI atau sebagainya (5). Dia mampu mengelolah usaha taninya (6). Dia harus melakukan pemasaran berkelompok bukan per individu (7). Dia mampu bermitra apakah dengan pihak perusahaan maupun swasta" (Wawancara, SF)

Berdasarkan hasil wawancara diatas menunjukkan bahwa yang menjadi indikator kelompok tani layak dikatakan mandiri yaitu ketika memenuhi unsur yang diatas dalam artian bahwa kelompok tani harus mempunyai kelengkapan buku administrasi dan lainlain karena ketika kelompok tani sudah lengkap buku administrasinya berarti bisa dikatakan bahwa kelompok tani itu aktif dalam mengembangkan usaha taninya dan mereka wajib melakukan pertemuan kelompok minimal satu kali sebulan untuk membahas masalahmasalah yang dihadapinya dalam melakukan usaha taninya sehingga kelompok tani mampu 
menghadapi masalah-masalah yang ada dalam kelompok tani itu sendiri. Agar kelompok tani mampu memenuhi unsur yang diatas maka dibutuhkan strategi atau peran pemerintah daerah dalam melakukan pemberdayaan kelompok tani di Desa Lasiai sehingga unsurunsur diatas bisa terpenuhi.

\section{Kajian Analisis SWOT Dalam Pemberdayaan Kelompok Tani, Di Desa Lasiai, Kecamatan Sinjai Timur, Kabupaten Sinjai.}

Analisis SWOT adalah cara menganalisis faktor internal dan faktor eksternal menjadi langkah strategi dalam pengoptimalan usaha yang lebih menguntungkan (Rangkuti, 2005). Analisis SWOT adalah bagian penting dari manajemen strategis proses perencanaan (Pickton, dkk. 1998). Analisis SWOT didesain untuk digunakan dalam tahap awal pengambilan keputusan dan sebagai perencanaan strategis di berbagai jenis aplikasi.

\section{a) Kekuatan (Strengths)}

Kekuatan (strengths) adalah bagaimana kekuatan strategi ataupun cara seseorang untuk menggapai tujuan dengan maksimal agar strategi yang dijalankan bisa produktif. Berikut hasil kutipan wawancara dengan beberapa informan terkait dengan indikator penyediaan informasi seperti berikut:

"Begini kalau dinas pertanian tanaman pangan dan holtikultura yang dilakukan itu dalam hal pemberdayaan kelompok tani kita hanya memberikan bantuan dana, bantuan pupuk bersubsidi dan obatobatan untuk membasmi hama, memberikan sarana dan prasarana seperti hendtraktor, pompa air, dan dinas pertanian juga kadang-kadang melakukan penyuluhan kepada kelompok tani tentang bagaimana mendeteksi sebelum terjadi serangan hama yang mengakibatkan gagal panen. Karena dinas pertanian tanaman dan holtikulura bukan tugas pokoknya melakukan penyuluhan kepada kelompok tani tapi tugas pokoknya Bapel yaitu badan penyuluhan, kami disini hanya memberikan bantuan dana dan fasilitas lainnya" (Wawancara, SD)
Wawancara diatas menunjukkan bahwa adanya peran pemerintah dalam hal melakukan pemberdayaan kelompok tani misalnya pemerintah daerah memberikan bantuan dana, bantuan pupuk dan obat-obatan yang tujuannya bagaimana kelompok tani bisa meningkatkan pendapatannya dari hasil pertaniannya. Dan pemerintah kadangkadang melakukan penyuluhan kepada kelompok dalam hal pemberdayaan kelompok tani tapi perlu ditegaskan bahwa melakukan penyuluhan kepada kelompok tani bukan tugas pokoknya dinas pertanian tanaman pangan dan holtikultura. Tapi melakukan penyuluhan kepada kelompok tani adalah tugas pokoknya badan penyuluhan yang paling berperan penting dalam melakukan pemberdayaan kelompok tani.

\section{b. Kelemahan (Weakneass)}

Kelemahan (Weakneas) yaitu bagaimana kelemahan strategi ataupun seseorang yang tidak bisa menggapai tujuan dengan maksimal sehingga strategis yang dijalankan tidak produktif.

Berikut hasil kutipan wawancara dengan beberapa informan terkait dengan indikator penyediaan informasi seperti berikut:

"Kelemahan pemerintah masih kurang penyediaan sarana dan prasarana terutama infrastruktur jalan sehingga pemasaran hasil pertanian tidak efektif dan pelayanan pemerintah belum maksimal, misalnya saya sudah tiga kali kasih masuk proposal bantuan sarana dan prasarana tapi tidak adapi yang keluar, kelemahan juga pemerintah dalam melakukan penyuluhan kepada kelompok tani belum efektif lah, kadang satu bulan satu kali diadakan pembinaaan dan pelatihan kepada kita, kadangkadang juga dalam satu bulan pemerintah 
tidak melakukan penyuluhan kita, penyuluh pertanian belum merata dalam melakukan penyuluhan kepada kita, misalnya kelompok tani disebelah sering dilakukan penyuluhan" (Wawancara, KR)

Wawancara diatas menunjukkan bahwa adanya kelemahan dalam peran pemerintah yang seharusnya menunjang kelompok tani dengan cara menyediakan sarana dan prasarana yang menunjang dalam melakukan usaha taninya. Dan seharusnya pemerintah melakukan penyuluhan kepada kelompok tani dengan maksimal sehingga kemandirian kelompok tani dapat tercipta, maka dibutuhkan peran pemerintah dalam meningkatkan kemandirian kelompok tani dengan cara melakukan penyuluhan kepada setiap kelompok tani tujuannya adalah peningkatan kemampuan dan keterampilan dalam melakukan usaha taninya sehingga hasil pertanian meningkat dan dapat meningkatkan kesejahteraan anggota kelompok tani itu. Maka kelompok tani membutuhkan konsistensi pemerintah dalam melakukan pemberdayaan kepada kelompok tani sehingga tujuan yang ingin dicapai dapat terpenuhi, maka pemerintah harus konsisten dalam melakukan pemberdayaan kepada kelompok tani yang ada di Desa Lasiai.

\section{c. Peluang (Opportunity)}

Peluang (Opportunity) adalah bagaimana peluang strategi ataupun cara seseorang untuk menggapai tujuan dengan memanfaatkan peluang dengan maksimal agar strategi yang dijalankan bisa produktif. Berikut hasil kutipan wawancara dengan beberapa informan terkait dengan indikator penyediaan informasi seperti berikut:

"Kalau peluang banyak apalagi penyuluh sekarang aktif dalam melakukan penyuluhan, itulah yang menjadi peluang bagi kita ada adanya dukungan dana dari pemerintah sehingga dalam melakukan usaha taniya bisa maksimal dan sangat memungkinkan para petani dimana masih banyak lahan kosong yang bisa dimanfaatkan untuk bertani" (wawancara, $D R)$

Wawancara diatas berbicara soal peluang dimana peluang terjadi apabila seseorang menjalankan sebuah pekerjaan dengan serius atau setidaknya untuk mendapatkan peluang itu. Berbicara soal pemberdayaan kelompok tani dimana peluang sangat besar bagi kelompok tani untuk meningkatkan kemampuan dan keterampilan kelompok tani untuk mampu mandiri dan bisa meningkatkan kesejahteraanya, dengan adanya penyuluhan yang aktuf melakukan pembinaan dan pelatihan kelompok dalam hal penguatan kelembagaan kelompok tani, apa lagi adanya dukungan dana dari pemrintah sangat membantu kelompok tani dalam melakukan usaha taninya dan apalagi lapangan kerja dibidang pertanian masih luas karena masih banyak lahan yang kosong itu memungkinkan kelompok tani untuk meningkatkan penghasilan dari usaha taninya. Dimana adanya peran pemerintah yang sangat membantu kelompok tani untuk mampu mandiri dan mampu meningkatkan kesejahteraanyaa.

\section{d. Tantangan/Ancaman (Treaths)}

Tantangan (Treaths) adalah bagaimana tantangan strategi ataupun cara seseorang untuk menggapai tujuan dengan mengatasi tantangan itu dengan maksimal agar strategi yang dijalankan bisa produktif

Berikut hasil wawancara dengan beberapa informan terkait dengan indikator penyediaan informasi seperti berikut:

Lima tahun terakhir itu ada beberapa ancaman dari kelompok tani, merupakan suatu tantangan bagi petani, sehingga itu yang menghambat dalam peningkatan produksi pertanian. Saya sudah bicara sama sudah diusulkan ke dinas pertanian tanaman pangan dalam mengatasi penyakit itu, tapi belum ada tindak lanjut dari pemerintah, mestinya pemerintah secepatnya menindak lanjuti hama ini karena lima tahun terakhir meresahkan petani, ada memang dibidang pertanian yang menangani, hama kami hanya menginformasikan kedinas. (wawancara,SF). 
Wawancara diatas berbicara soal tantangan dimana dalam menjalankan hal apapun untuk menjadi lebih baik harus melewati namanya tantangan. Apabila seseorang menjalankan sebuah pekerjaan dengan serius maka tantangan mudah di atasi dan diselesaikan dengan baik, berbicara soal pemberdayaan kelompok tani yang dimana pasti harus melalui tantangan pemerintah maupun tantangan bagi kelompok tani semua pasti ada tantangan masing-masing untuk berbenah. Bagaimana kita bisa mengatasi hama-hama yang menyerang tanaman sehingga kelompok tani tidak mengalami gagal panen. Maka dibutuhkan peran pemerintah dalam membantu kelompok tani dalam mengatasi hama-hama yang menyerang sehingga kelompok tani tidak mengalami kerugian dan sehingga kelompok tani mampu meningkatkan kesejahteraannya.

\section{Strategi Pemerintah Daerah Dalam Pemberdayaan Kelompok Tani Di Desa Lasiai, Kecamatan Sinjai Timur, Kabupaten Sinjai}

Setelah membahas beberapa model analisis SWOT di atas, kini akan ditampilkan sebuah model yang cukup komprehensif dan secara terinci melengkapi semua model tersebut. Model ini disebut Matriks TOWS yang dikembangkan oleh David (1989). David tidak memakai singkatan SWOT seperti yang lazim di dengar, tetapi lebih senang menggunakan TWOS yang tampaknya ingin mendahulukan analisis ancaman dan peluang untuk kemudian melihat sejauh mana kapabilitas internal sesuai dan cocok dengan faktor-faktor eksternal tersebut. Tidak menjadi persoalan, apakah suatu organisasi itu adalah organisasi militer, olaraga, bisnis, pemerintahan, kesenian, sosial, politik, atau yang lainnya. Pokoknya mereka hendaknya berusaha mengembangkan strategi untuk maju atau bertahan.

Strategi SO dimana pakai kekuatan untuk memanfaatkan peluang atau perkawinan antara strenght dan opportunities, dimana akan timbul strategi model Matriks TOWS, beberapa model yang cukup komprehensif dan secara terinci melengkapi semua model diatas analisis SWOT sehingga, peluang yang kita rencanakan bisa berjalan dengan baik dengan cara memanfaatkan kekuatan-kekuatan yang kita punya.

"Kalau persilangan antara kekuatan dan peluang, semuanya positif artinya bahwa, apalagi kekuatan dan peluang bisa dijalankan bersamaan baik itu yang menjadi kekuataan maupun yang menjadi peluang, misalnya adanya bantuan dari pemerintah sehingga peluang bisa berjalan dengan baik, ada power kemudian ada peluang, itu sangat luar biasa sehingga kekurangan bisa diatasi" (wawancara, $H S$ )

Dalam wawancara keinforman selaku petani yang tergabung dalam kelompok tani yang membahas soal strenght dan opportunities atau kekuatan dan peluang dimana petani menginginkan kekuatan menjadi suatu daya yang bisa diandalakan untuk melakukan usaha taninya. Agar para petani yang tergabung dalam kelompok tani itu bisa mandiri dan bisa meningkatkan kesejahteraannya dan peluang yang ada bisa memperkuat kekuatan yang ada agar semua pengaruh dari luar yang bersifat negative bisa diatasi dengan gabungan kekuatan dan peluang sehingga kemandirian kelompok tani bisa tercipta dan bisa meningkatkan kesejahteraan para petani.

Strategi WO dimana menanggulangi kelemahan dengan memanfaatkan peluang, untuk menanggulangi kelemahan dengan memanfaatkan peluang kita akan mengunakan metode perkawinan anatara weaknesses dan opportunities, dimana akan timbul strategi model Matriks TOWS, beberapa model yang cukup komprehensif dan secara terinci melengkapi semua model diatas analisis SWOT sehingga, yang kita rencanakan bisa berjalan dengan baik dengan cara memanfaatkan peluangpeluang yang kita punya untuk menanggulangi kelemahan yang ada misalkan kelemahan Dana yang terbatas, 
Kesadaran kelompok tani maupun keaktifan kelompok tani dalam mengikuti penyuluhan, Penguasaan informasi dan penguasaan teknologi modern masih rendah, Sikap dan prilaku petani masih rendah maupun SDM petani masih rendah, masih kental pemahaman tradisional, Penyuluhan yang dilakukan pemerintah belum maksimal, dan Penyedian sarana dan prasarana masih kurang, kelemahan itu bisa kita atasi dengan memanfaatkan peluang-peluang yang ada misalkan Dukungan dana dari pemerintah, Adanya pasar, Masih banyak lahan kosong dibidang pertanian, Kondisi geografis atau kondisi tanah, Adanya kerjasama antara dinas pertanian tanaman pangan dan holtikultura dengan badan penyuluhan.

"Bagaimana mengatasi kelemahan itu, maka dibutuhkan keterpaduan antara kelemahan dengan peluang, bagaimana kita mengatasi kelemahan itu dengan memanfaatkan peluang yang ada, misalnya dana yang terbatas, maupun sarana dan prasarana masih kurang, tapi dengan adanya peluang misalnya dukungan dana dari pemerintah, bisa diatasi kelemahan itu. (wawancara, $R H$ )

Dalam wawancara informan selaku petani yang tergabung dalam kelompok tani yang membahas soal weaknesses dan opportunities atau kelemahan dan peluang dimana kelemahan yang dikwatirkan oleh kelompok tani dalam melakukan usaha taninya yang membuat hasil pertanian kelompok tani tidak maksimal. bagaimana kita mengatasi kelemahan itu dengan baik, maka kita harus memanfaatkan peluang yang ada sehingga kelemahan-kelemahan itu bisa diatasi dengan baik

Strategi ST dimana pakai kekuatan untuk menghindari ancaman dengan menggunakan motede perkawinan antara strength dan threats, dimana akan timbul strategi model Matriks TOWS, berapa model yang cukup komprehensif dan secara terinci melengkapi semua model diatas analisis SWOT, sehingga peluang yang kita rencanakan bisa berjalan dengan baik, dengan cara memanfaatkan kekuatan-kekuatan yang kita punya untuk menghindari sebuah ancaman dilembaga atau sebuah organisasi kita, kekuatan yang ada harus bisa menjadi perlindungan dari sebuah ancaman atau tantangan misalnya ancaman yaitu Serangan organisme penggangu tanaman maupun hama-hama, Harga jual produk pertanian sangat berubah-berubah dan Pemasaran hasil pertanian, sehingga kekuatan sangat dibutuhkan untuk menghindari ancaman misalkan memanfaatkan kekuatan yaitu adanya penyuluhan, adanya bantuan, adanya sarana dan prasarana dan adanya kebijakan pemerintah dalam hal peningkatan kesejahteraan petani dan pengembangan pertanian. Sehingga ancaman itu bisa diatasi dengan baik karena ada kekuatan-kekuatan yang mendukung.

"Bahwa kita ada ancaman tapi ada kekuatan contoh adanya bantuan dari pemerintah misalnya bantuan dana, sehingga ancaman-ancaman bisa diatasi yaitu adanya serangan hama,itu bisa diatasi dengan bantuan dana dengan membelikan racun untuk membasmi hamahama" (wawancara, AS)

Dalam wawancara keinforman selaku kelompok tani yang membahas soal metode perkawinan antara strenght dan threats atau kekuatan dan ancaman dimana metode perkawinan antara kekuatan dengan ancaman. Bagaimana mengatasi ancaman dengan mengandalkan kekuatan yang ada sehingga ancaman-ancaman bisa diatasi dengan baik karena kekuatan yang mendukung, misalnya adanya gangguan serangan hama, ancaman luar ini bisa diatasi dengan adanya kekuatan misalnya adanya bantuan dari pemerintah baik itu berupa dana maupun racun untuk membasmi hamahama, sehingga hasil pertanian meningkat dan dapat meningkatkan kesejahteraan para kelompok tani.

Strategi WT dimana memperkecil kelemahan dengan menghindari ancaman, untuk memperkecil kelemahan dengan menghindari ancaman kita akan 
menggunakan metode perkawinan antara weaknesses atau threats dimana akan timbul strategi model Matriks TOWS, beberapa model yang cukup komprehensif dan secara terinci melengkapi semua model diatas analisis SWOT sehingga untuk memperkecil kelemahan agar berjalan dengan baik sehingga bisa menghindari sebuah ancaman dari luar maupun kelemahan dari dalam agar semua bisa berjalan dengan baik maka kita harus memanfaatkan sebuah kelemahan untuk memperkecilnya agar tidak meluas. Misalkan kelemahan kelemahan Dana yang terbatas, Kesadaran kelompok tani maupun keaktifan kelompok tani dalam mengikuti penyuluhan, Penguasaan informasi dan penguasaan teknologi modern masih rendah, Sikap dan prilaku petani masih rendah maupun SDM petani masih rendah, masih kental pemahaman tradisional, Penyuluhan yang dilakukan pemerintah belum maksimal, dan Penyedian sarana dan prasarana masih kurang, semua kelemahan itu bisa dipecahkan dengan memanfaatkan atau memperkecil agar tidak meluas ancaman-anacaman misalkan Serangan organisme penggangu tanaman maupun hama-hama, Harga jual produk pertanian sangat berubah-berubah dan Pemasaran hasil pertanian, sehingga dibutuhkan bagaimana memperkecil kelemahan agar ancaman itu ditakutkan akan timbul dan bisa memperluas sebuah kelemahan.

Itu ketemu luar biasa bahaya, dana yang terbatas ,ancaman juga datang, bagaimana mengatasi ancaman itu agar tidak terjadi ada tindakan awal, dari awal kita perbaiki,sehingga bisa memperkecil kelemahan dan menghindari ancaman. (wawancara, BT)

Dalam wawancara ke informan selaku petani yang tergabung dalam kelompok tani yang membahas metode perkawinan antara weaknesses dan threats atau kelemahan dan ancaman dimana metode perkawinan ini sebagai strategi pemerintah dalam mengatasi semua masalah yang ada khususnya dalam peningkatan kemandirian kelompok tani, dimana kelemahan dan ancaman itu adalah masalah besar dalam sebuah organisasi maupun pekerjaan, bagaimana mengatasi kelemahan dan ancaman ini harus diatasi dengan baik supaya tidak akan meluas untuk menghancurkan kekuatan dan peluang yang ada, maka harus sebaliknya kekuatan dan peluang yang ada harus menghentikan pergerakan kelemahan dan ancaman dari luar maupun kelemahan atau faktor dari dalam.

\section{Faktor Pendukung Dan Penghambat Dalam Melakukan Pemberdayaan Kelompok Tani Di Desa Lasiai, Kecamatan Sinjai Timur, Kabupaten Sinjai}

Tentunya dalam melakukan pemberdayaan kelompok tani pasti dipengaruhi oleh dua faktor yang pertama adalah faktor pendukung adalah faktor yang mendukung proses jalannya pemberdayaan kepada kelompok tani yang dilakukan oleh pemerintah daerah. Yang kedua adalah faktor penghambat yaitu faktor yang menghambat proses jalannya pemberdayaan kepada kelompok tani yang dilakukan oleh pemerintah daerah.

\section{a. faktor pendukung}

faktor pendukung adalah faktor yang mendukung proses jalannya pemberdayaan kepada kelompok tani yang dilakukan oleh pemerintah daerah. Dalam artian adalah faktor yang menunjang dalam melakukan pemberdayaan kepada kelompok tani sehingga pemberdayaan yang dilakukan oleh pemerintah berjalan maksimal.

Berikut hasil kutipan wawancara dengan beberapa informan yang terkait faktor pendukung pemerintah dalam melakukan pemberdayaan kelompok tani di Desa Lasiai.

Adanya dukungan sarana dan prasarana penyuluh, sehingga pemerintah dalam melakukan penyuluhan berjalan maksimal karena adanya dukungan sarana 
dan prasarana. Dan memang saat ini Alhamdulillah sudah mulai bagus, diantara semua penyuluh yang ada disini yang diperlukan kebutuhan sarana prasarana misalnya motor dinas semua punya, sehingga kita bisa menjangkau di daerah-daerah untuk melakukan Pemberdayaan kelompok tani. Yang kedua yang menjadi faktor pendukung adalah adanya dukungan dana misalnya biaya operasional penyuluh dan masih perlu dukungan dana ditingkatkan (wawancara, SF)

Bedasarkan hasil wawancara diatas menunjukkan bahwa adanya dukungan bagi pemerintah dalam melakukan pemberdayaan kepada kelompok tani yang ada di desa lasiai misalnya dukungan dana dan sarana prasarana yang menunjang dalam melakukan pemberdayaan kepada kelompok tani sehingga terwujudnya kemandirian kelompok tani di Desa Lasiai. Dengan adanya dukungan sarana dan prasarana maupun dana sangat membantu pemerintah khususnya penyuluh dalam melakukan pemberdayaan kepada kelompok tani sehingga pemberdayaan yang dilakukan berjalan lancar karena adanya dukungan sarana prasarana maupun bantuan dana.

\section{b. faktor penghambat}

Faktor penghambat yaitu faktor yang menghambat proses jalannya pemberdayaan kepada kelompok tani yang dilakukan oleh pemerintah daerah. Berikut hasil kutipan wawancara dengan beberapa informan yang terkait faktor penghambat pemerintah dalam melakukan pemberdayaan kelompok tani di Desa Lasiai.

"yang menghambat itu partisipasi kelompok tani, ini yang saya katakan tadi tidak semua kelompok bersedia mudah atau mampu mengakomodir apa yang kita sampaikan, kami selaku penyuluh bermitra dengan petani, misalnya kita sampaikan besok kita ada kegiatan seperti ini mereka mengumpulkan anggotanya, tidak semua kelompok mau seperti itu" (wawancara, SF)

Bedasarkan hasil wawancara diatas menunjukkan bahwa adanya faktor penghambat bagi pemerintah dalam melakukan pemberdayaan kepada kelompok tani yang ada di desa lasiai yang menghambat itu partisipasi kelompok tani dalam mengikuti pemberdayaan yang dilakukan oleh pemerintah. Artinya salah satu masalah yang dihadapi oleh pemerintah dalam melakukan pemberdayaan kelompok tani adalah masalah partisipasi kelompok tani dalam mengikuti penyuluhan yang dilakukan oleh pemerintah, agar pemberdayaan yang dilakukan oleh pemerintah berjalan maksimal maka dibutuhkan kesadaran kelompok tani dalam mengikuti pemberdayaan kelompok tani.

\section{H. PENUTUP}

Bahwa kondisi kelembagaan atau tingkat keterberdayaan kelompok tani yang ada di Desa Lasiai, sudah mulai bagus, ada perubahan. Maka dibutuhkan konsistensi pemerintah maupun kelompok tani untuk mempertahankan semua itu sehingga kedepannya bisa tercapai kemandirian kelompok tani di Desa Lasiai, kelompok tani yang ada di Desa Lasiai rata-rata berada pada ketegori lanjut dan madya.

Kekuatan (strengths) adalah menunjukkan bahwa adanya peran pemerintah dalam hal melakukan pemberdayaan kelompok tani misalnya pemerintah daerah memberikan bantuan dana, bantuan pupuk dan obat-obatan yang tujuannya bagaimana kelompok tani bisa meningkatkan pendapatannya dari hasil pertaniannya.. Kelemahan (Weakneas) yaitu bahwa adanya kelemahan dalam peran pemerintah yang seharusnya menunjang kelompok tani dengan cara menyediakan sarana dan prasarana yang menunjang dalam melakukan usaha taninya. Peluang (Opportunity) adalah peluang dimana peluang terjadi apabila seseorang menjalankan sebuah pekerjaan dengan serius atau setidaknya untuk 
mendapatkan peluang itu. Tantangan (Treaths) adalah mengatasi hama-hama yang menyerang tanaman sehingga kelompok tani tidak mengalami gagal panen.

Faktor pendukung dan penghambat dalam melakukan pemberdayaan kelompok tani di Desa Lasiai, Kecamatan Sinjai Timur, Kabupaten Sinjai. Faktor pendukung adalah faktor yang mendukung proses jalannya pemberdayaan kepada kelompok tani yang dilakukan oleh pemerintah daerah. Dalam artian adalah faktor yang menunjang dalam melakukan pemberdayaan kepada kelompok tani sehingga pemberdayaan yang dilakukan oleh pemerintah berjalan maksimal. Faktor penghambat yaitu faktor yang menghambat proses jalannya pemberdayaan kepada kelompok tani yang dilakukan oleh pemerintah daerah.

Pemerintah harus memperhatikan kelompok tani atau membantu dan menunjang kelompok tani dalam melakukan usahataninya sehingga bisa meningkatkan kesejahteraan para petani yang tergabung dalam kelompok tani. Pemerintah harus membantu kelompok tani baik dalam hal pengadaan sarana dan prasarana pertanian maupun bantuan dana dan lain-lain. Pemerintah harus melakukan pemberdayaan kepada kelompok tani baik dalam hal penyuluhan harus maksimal sehingga bisa meningkatkan kemampuan dan keterampilan kelompok tani untuk mampu mandiri dan bisa meningkatkan kesejahteraannya.

\section{DAFTAR PUSTAKA}

Marrus, S, K. 2002. Desain Penelitian Manajemen Strategik, Jakarta : Rajawali
Press.

Pickton, W. D dan Wright S. 1998. What's SWOT In Strategic Analysis?. Strategic Change, 7(2), 101-109.

Rangkuti, F. 2005. Teknik Membuat Perencanaan Bisnis Dan Analisis Kasus. Jakarta : PT Gramedia Pustaka Utama

Suharto, Edi. 2005. Membangun masyarakat memberdayakan rakyat; kajian strategis pembangunan kesejahteraan sosial dan pekerja sosial, Bandung : Refika Aditama.

Dokumen :

UU No 23 Tahun 2014 dalam Pasal 1, Tentang Pemerintahan Daerah

Peraturan Menteri Pertanian No. 273/KPTS/OT.160/4/2007 tentang tentang Pedoman Pembinaan Kelembagaan Petani, Jakarta 